\title{
PRKACA wt Allele
}

National Cancer Institute

\section{Source}

National Cancer Institute. PRKACA wt Allele. NCI Thesaurus. Code C51267.

Human PRKACA wild-type allele is located in the vicinity of 19p13.1 and is approximately $26 \mathrm{~kb}$ in length. This allele, which encodes CAMP-dependent protein kinase, alpha-catalytic subunit protein, plays a role in the phosphorylation of numerous cytoplasmic and nuclear proteins in response to activation by the signaling molecule cyclic AMP. 